\title{
О.М. Никифорук
}

\section{Чи реально при ультрасонографії діагностувати перфоративний апендицит у дітей?}

\author{
Львівський національний медичний університет імені Данила Галицького, Україна
}

Paediatric surgery.Ukraine.2019.4(65):25-29; DOI 10.15574/PS.2019.65.25

For citation: Nykyforuk OM. (2019). Is it really possible to diagnose perforated appendicitis with an ultrasound in children? Paediatric Surgery.Ukraine. 4(65): 25-29. doi 10.15574/PS.2019.65.25

Гострий апендицит є однією з найчастіших патологій у дітей, яка вимагає хірургічного втручання. Ультрасонографія (УСГ) розглядається як перший метод інструментальної діагностики у дітей із гострим апендицитом. Незважаючи на численні дослідження щодо УСГ-діагностики гострого апендициту, питання можливості застосування цього методу для розмежування неускладненого та ускладненого гострого апендициту, зокрема перфоративного, вивчені недостатньо.

Мета: провести ретроспективний аналіз результатів УСГ-обстеження у порівнянні з інтраопераційними знахідками щодо визначення УСГ-критеріїв гострого перфоративного апендициту.

Матеріали і методи. Робота грунтується на результатах УСГ-обстеження та хірургічного лікування 97 дітей у І хірургічному відділенні КНП ЛОР «Львівська обласна дитяча клінічна лікарня «ОХМАТДИТ» упродовж дев'яти місяців 2019 року.

УСГ виконували за протоколом, який включав огляд усіх ділянок черевної порожнини, з ретельним обстеженням правої клубової ділянки з використанням дозованої компресії. Діагноз перфоративного апендициту встановлювали за наявності видимого перфоративного отвору під час хірургічного втручання. Наявність гангренозного апендициту без перфоративного отвору, навіть за наявності періапендикулярного абсцесу, не розглядали як перфоративний апендицит.

Результати. Перфоративний апендицит діагностовано у 29 (29,9\%) пацієнтів. При УСГ збільшення максимального діаметра червоподібного відростка виявлено у 23 (79,3\%), у 19 (65,5\%) - потовщання стінки відростка >3 мм, втрату ехогенності підслизового шару стінки відростка та наявність випоту - у $12(41,4 \%)$ і в 11 (37,9\%) пацієнтів діагностовано наявність копроліту у просвіті відростка та запальні зміни уперіапендикулярній жировій тканині. Незважаючи на те, що у дітей із перфоративним апендицитом часто виявляли збільшення максимального діаметра відростка, ці зміни не $є$ специфічними для даної форми захворювання. Інші показники також мають низькі показники чутливості і/або специфічності щодо наявності перфорації червоподібного відростка.

Висновки. Ультрасонографія має високу специфічність, проте досить низьку чутливість, для визначення наявності перфоративного апендициту у дітей. Збільшення максимального діаметра червоподібного відростка, потовщання його стінки (>3 мм) та порушення ехогенності підслизового шару можна розглядати як основні УСГ-ознаки перфоративного апендициту у дітей, проте вони повинні оцінюватись лише у комплексі з даними об’єктивного обстеження та іншими УСГ-ознаками.

Дослідження виконані відповідно до принципів Гельсінської Декларації. Протокол дослідження ухвалений Локальним етичним комітетом установи. На проведення досліджень було отримано поінформовану згоду батьків (опікунів) дітей.

Автор заявляє про відсутність конфлікту інтересів.

Ключові слова: діти, гострий перфоративний апендицит, діагностика, ультрасонографія. 


\section{Is it possible to diagnose perforative appendicitis in children with ultrasound? \\ O.M. Nykyforuk}

Danylo Halytsky Lviv National Medical University, Ukraine

Acute appendicitis is one of the most common pathologies in children that requires surgery. Ultrasonography (US) is considered as the first method of instrumental diagnosis in children with acute appendicitis. Despite numerous studies on US diagnostics of acute appendicitis, questions of ability of this method to separate uncomplicated and complicated acute appendicitis, in particular perforated, have not been studied enough.

Aim of the study was to conduct a retrospective analysis of the results of US compared with intraoperative findings regarding the determination of US criteria for perforated acute appendicitis.

Materials and Methods. The study is based on the results of US examination and surgical treatment of 97 children at surgical department of Lviv regional children's clinical hospital «OXMATDYT» during 9 months of 2019.

US was done according to the protocol, that includes an examination of all regions of abdominal cavity with a thorough examination of the right iliac region using the method of graded compression. The diagnosis of perforated appendicitis was established during surgery by the presence of a visible perforated hole. The presence of gangrenous appendicitis without a perforated hole, even in the presence of periappendicular abscess, was not considered as perforated appendicitis.

Results. Perforated appendicitis was diagnosed in 29 (29.9\%) patients. During US, an increase of maximal diameter of the appendix was found in 23 (79.3\%), in $19(65.5 \%)$ - thickening of the appendix wall $>3 \mathrm{~mm}$, loss of echogenicity of submucosal layer of the appendix wall and presence of fluid - in 12 (41.4\%) and in $11(37.9 \%)$ patients were diagnosed with fecalith in the lumen of the appendix and inflammatory changes in the periappendiceal adipose tissue. Although children with perforated appendicitis often have an increase of maximal diameter of the appendix, these changes are not specific to this form of the disease. Other indicators also have low sensitivity and/or specificity for the presence of perforation of the appendix.

Conclusions. Ultrasonography has high specificity, but low enough sensitivity to determine the presence of perforated appendicitis in children. Increasing of maximal diameter of the appendix, thickening of its wall $(>3 \mathrm{~mm}$ ) and impaired echogenicity of the submucosal layer can be considered as the main US symptoms of perforated appendicitis in children, but they should be evaluated only in conjunction with physical examination data and other US symptoms. The research was carried out in accordance with the principles of the Helsinki Declaration. The study protocol was approved by the Local Ethics Committee of institution. The informed consent of the patient was obtained for conducting the studies.

No conflict of interest was declared by the author.

Key words: children, acute perforated appendicitis, diagnostic, ultrasonography.

\section{Реально ли при ультрасонографии диагностировать перфоративный аппендицит у детей? \\ О.М. Никифорук}

Львовский национальный медицинский университет имени Данила Галицкого, Украина

Острый аппендицит у детей является одной из наиболее частых патологий, требующей хирургического вмешательства. Ультрасонография (Усг) рассматривается как начальный метод инструментальной диагностики у детей с острым аппендицитом.

Несмотря на многочисленные исследования, посвященные УСГ-диагностике острого аппендицита, вопросы возможности применения этого метода для разделения неосложненного и осложненного острого аппендицита, в частности перфоративного, изучены недостаточно.

Цель: провести ретроспективный анализ результатов УСГ-обследования в сравнении с интраоперационными результатами относительно определения УСГ-критериев острого перфоративного аппендицита.

Материалы и методы. Работа основывается на результатах УСГ-обследования и хирургического лечения 97 детей в I хирургическом отделении КНП ЛОС «Львовская областная детская клиническая больница «ОХМАТДЕТ» на протяжении девяти месяцев 2019 года.

УСГ выполняли согласно протоколу, который включает осмотр всех отделов брюшной полости с тщательным обследованием правой подвздошной области с использованием метода дозированной компрессии. Диагноз перфоративного аппендицита устанавливали во время хирургического вмешательства при наличии видимого перфоративного отверстия. Наличие гангренозного аппендицита без перфоративного отверстия, даже при наличии периаппендикулярного абсцесса, не рассматривали как перфоративный аппендицит.

Результаты. Перфоративный аппендицит диагностирован у 29 (29,9\%) пациентов. При УСГ увеличение максимального диаметра червеобразного отростка выявлено у $23(79,3 \%)$, у 19 (65,5\%) - утолщение стенки отростка >3 мм, потерю эхогенности подслизистого слоя стенки отростка и наличие выпота - у 12 (41,4\%), у 11 (37,9\%) пациентов диагностировано наличие копролита в просвете отростка и воспалительные изменения в периаппендикулярной жировой ткани. Несмотря на то, что у детей с перфоративным аппендицитом часто выявляли увеличение максимального диметра отростка, эти изменения неспецифичны для данной формы заболевания. Другие показатели также имеют низкие значения чувствительности и/или специфичности относительно наличия перфорации червеобразного отростка.

Выводы. Ультрасонография обладает высокой специфичностью на фоне достаточно низкой чувствительности для определения наличия перфоративного аппендицита у детей. Увеличение максимального диаметра червеобразного отростка, утолщение его стенки (>3 мм) и нарушение эхогенности подслизистого слоя можно рассматривать как основные УСГ-симптомы перфоративного аппендицита у детей, однако они должны оцениваться в комплексе с данными объективного исследования и другими УсГ-симптомами.

Исследование было выполнено в соответствии с принципами Хельсинкской Декларации. Протокол исследования был одобрен Локальным этическим комитетом учрежденя. На проведение исследований было получено информированное согласие родителей (опекунов) детей. Автор заявляет об отсутствии конфликта интересов.

Ключевые слова: дети, острый перфоративный аппендицит, диагностика, ультрасонография.

\section{Вступ}

Гострий апендицит є найчастішою причиною виникнення гострого абдомінального болю у дітей, що вимагає хірургічного втручання. Візуалізаційні методи обстеження є важливим компонентом підвищення точності діагностики гострого апендициту, зменшення кількості невиправданих апендектомій та запобігання зростанню частоти перфорацій [13].
Ультрасонографія (УСГ) у дітей, за рекомендаціями Американської педіатричної академії та Американської асоціації дитячих хірургів, вважається початковим методом інструментальної діагностики для підтвердження діагнозу гострого апендициту [10]. Для УСГ-діагностики гострого апендициту запропоновано багато критеріїв, які широко використовуються у клінічній практиці $[6,14,17]$, проте мож- 


\section{Оригінальні дослідження. Абдомінальна хірургія}

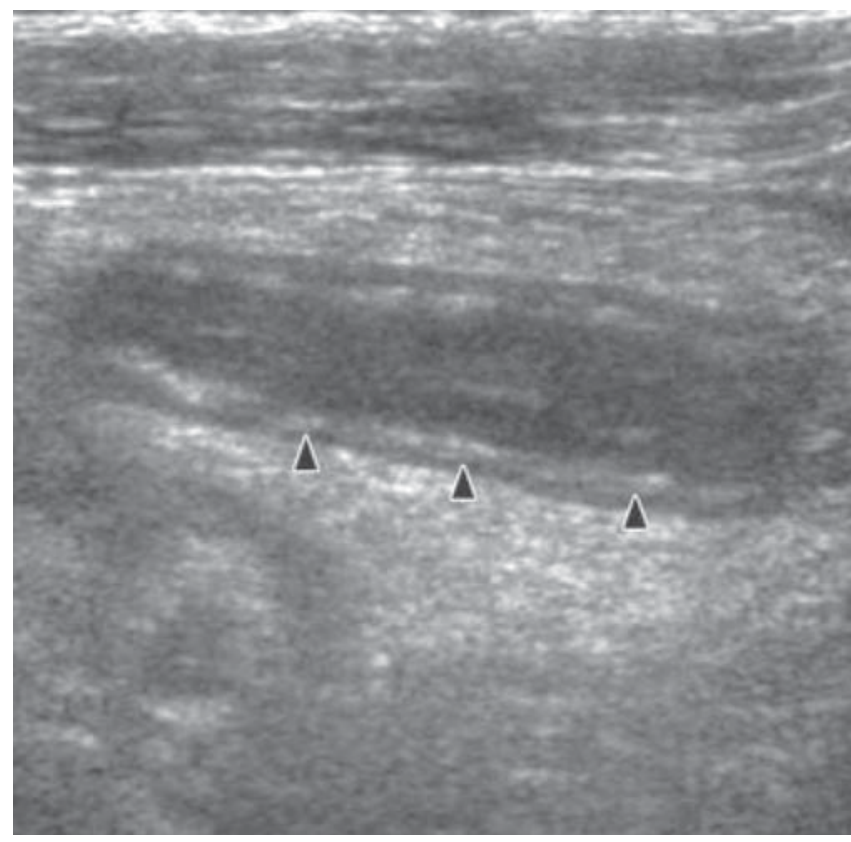

A

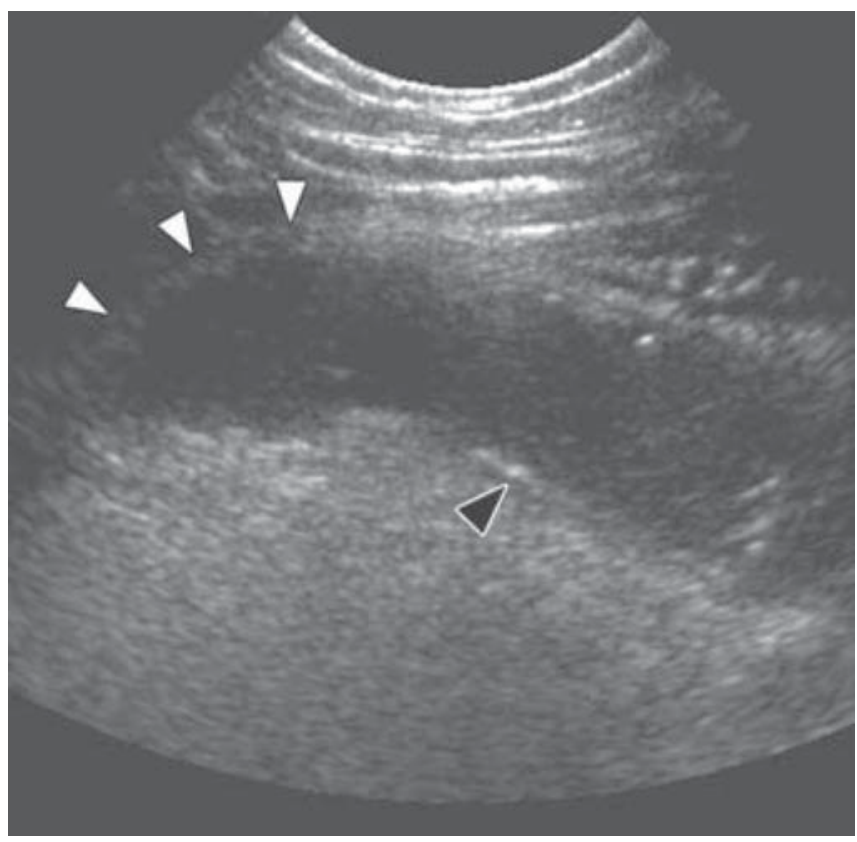

b

Рис. 1. Ехогенність підслизового шару при УСГ: А - збережена ехогенність підслизового шару (чорні наконечники) при гострому апендициті; Б - втрата ехогенності підслизового шару (білі наконечники) при перфорації відростка

ливості УСГ для розмежування неускладненого та ускладненого гострого апендициту, зокрема перфоративного, вивчені недостатньо.

Метою роботи було провести ретроспективний аналіз результатів УСГ-обстеження у порівнянні з інтраопераційними знахідками щодо визначення УСГ-критеріїв перфоративного гострого апендициту.

\section{Матеріал і методи дослідження}

Робота грунтується на результатах обстеження та хірургічного лікування 97 дітей, які були госпіталізовані у І хірургічне відділення КНП ЛОР «Львівська обласна дитяча клінічна лікарня «ОХМАТДИТ» упродовж дев'яти місяців 2019 року і яким проводили УСГ-обстеження перед хірургічним втручанням. Вік пацієнтів коливався від 3-х до 17 років (у середньому 9,3 $\pm 0,9$ року).

УСГ-обстеження поводили на апараті LOGIQ P7 General Electric, Корея) з використанням лінійних (5-10 МГц) та конвексних датчиків. УСГ виконували відповідно до протоколу, який включав огляд усіх ділянок черевної порожнини з ретельним обстеженням правої клубової ділянки з використанням дозованої компресії. При УСГ оцінювали діаметр червоподібного відростка, потовщення/стоншення стінки відростка, порушення ехогенності підслизового шару, наявність/відсутність випоту та його поширення, підвищення ехогенності періапендикулярної жирової тканини. Кольорову допплерографію застосовували в усіх пацієнтів з метою оцінки стану кровотоку у кишках у правій клубовій ділянці.

Діагноз перфоративного апендициту встановлювали за наявності видимого перфоративного отвору під час хірургічного втручання. Наявність гангренозного апендициту без перфоративного отвору, навіть за наявності періапендикулярного абсцесу, не розглядали як перфоративний апендицит.

Дослідження виконані відповідно до принципів Гельсінської Декларації. Протокол дослідження ухвалений Локальним етичним комітетом установи. На проведення досліджень було отримано поінформовану згоду батьків (опікунів) дітей.

\section{Результати дослідження та їх обговорення}

Частота перфорацій червоподібного відростка у дітей, за даними літератури, коливається від 15-20\% у підлітків до 60\% у дітей до 5 років, а у дітей молодше 3-х років - від 86\% до 100\% [1,2,12]. У нашому дослідженні перфорація відростка стверджена у $29(29,9 \%)$ пацієнтів.

За результатами УСГ червоподібний відросток вдалося візуалізувати у $83(85,6 \%)$ дітей, у тому числі в усіх пацієнтів із підтвердженим діагнозом перфоративного апендициту. Високій частоті виявлення червоподібного відростка сприяв метод дозованої компресії та використання низькочастотних датчиків, що збігається з даними літератури $[6,8]$.

Збільшення максимального діаметра червоподібного відростка є однією з УСГ-ознак гострого апен- 


\section{Оригінальні дослідження. Абдомінальна хірургія}

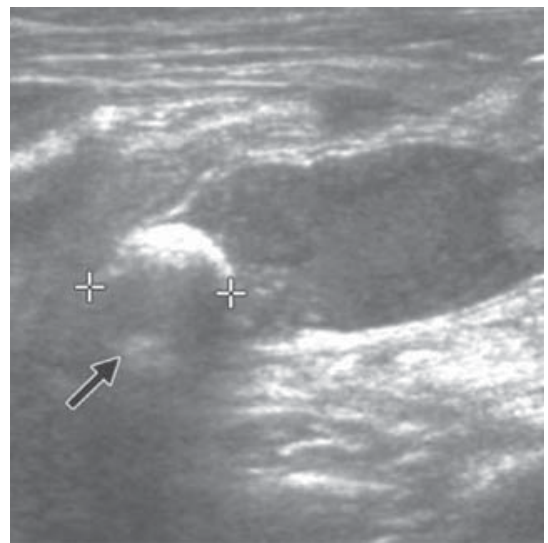

Рис. 2. Копроліт (курсори) у просвіті червоподібного відростка з наявною акустичною тінню (стрілка)

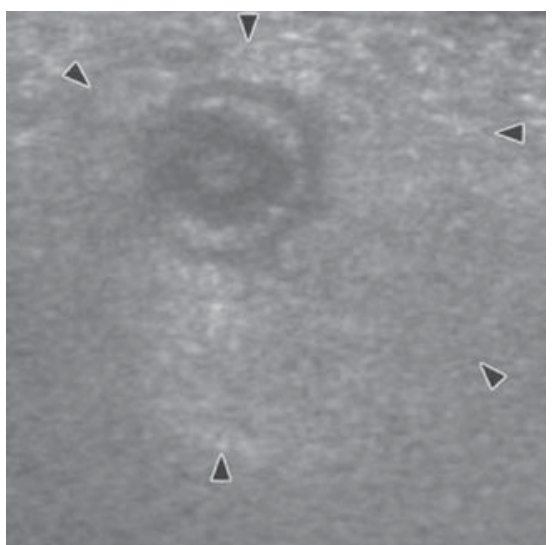

Рис. 3. Значна кількість гіперехогенної періапендикулярної жирової тканини, яка поширюється периферично (наконечники)

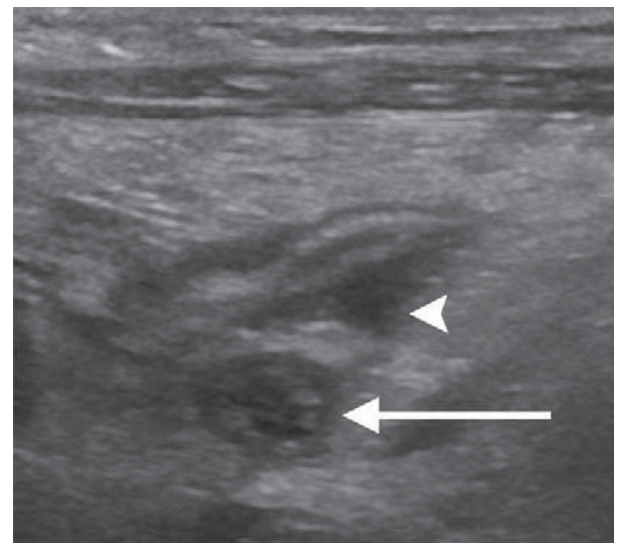

Рис. 4. Збільшений, з потовщеною стінкою, червоподібний відросток (стрілка). Випіт у періапендикулярній зоні (наконечник) дициту $[6,14]$. У наших дослідженнях дана ознака виявлена у $76(78,4 \%)$ пацієнтів, зокрема у $23(79,3 \%)$ - $з$ перфоративним апендицитом. Незважаючи на значну частоту цієї ознаки, вона не $є$ специфічною для даної форми захворювання, хоча середні показники максимального діаметра відростка були більшими у дітей з перфорацією порівняно 3

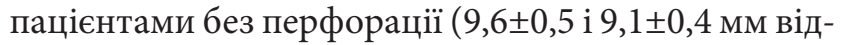
повідно), проте ця різниця статистично недостовірна $(\mathrm{p}>0,05)$. Такі результати корелюють із даними літератури [5].

Досить часто у дітей з перфоративним апендицитом при УСГ виявляли потовщання стінки відростка $>3$ мм (65,5\%, 19/29 дітей). Слід зазначити, що подібні ознаки виявляли й у пацієнтів без перфорації відростка, що зумовило низькі показники специфічності $(65,5 \%)$ та чутливості $(32,5 \%)$ цієї УСГ-ознаки по відношенню до перфоративного апендициту. Такі результати узгоджуються з даними літератури [16]. E. Blumfield зі співавт. (2013) вважають втрату ехогенності підслизового шару стінки відростка однією з УСГ-ознак перфоративного апендициту [3]. У наших дослідженнях дану ознаку виявили лише у $12(41,4 \%)$ дітей (рис.1), проте вона має високу специфічність (96\%) щодо наявності перфорації.

Копроліт у просвіті червоподібного відростка (рис. 2) виявлений у 27 (27,8\%) дітей, яких оперували з приводу гострого апендициту, а при перфоративному апендициті його виявили у 11 (37,9\%) пацієнтів. Тоді як дані літератури свідчать, що наявність копроліту (апендиколіту) є одним із чинників перфорації відростка $[4,15]$, а за даними Е. Blumfield та співавт. (2013), наявність апендиколіту у дітей молодше 8 років має чутливість $68 \%$ і специфічність $92 \%$ щодо наявності перфоративного апендициту [3].
За результатами нашого дослідження чутливість даної ознаки склала $37,9 \%$, а специфічність - 59,3\%.

Наявність змін у періапендикулярній жировій тканині розглядається як важливий критерій запальних захворювань, які локалізуються у правій клубовій ділянці [11]. За даними N. Kessler та співавт. (2004), зміни у періапендикулярній жировій тканині мають 91\% від’ємної прогностичної цінності і 76\% позитивної прогностичної цінності щодо діагнозу гострого апендициту [9]. Запальні зміни (рис. 3) у жировій тканині навколо червоподібного відростка виявили у 57 (58,8\%) дітей із гострим апендицитом, у тому числі в $11(37,9 \%)$ пацієнтів 3 перфоративним апендицитом. Оскільки такі зміни були стверджені й у дітей без перфорації, це зумовило низькі показники специфічності та чутливості (37,9\% і 67,6\% відповідно), що підтверджують й інші дослідники [3].

Наявність випоту у правій клубовій ділянці і/або у малому тазу виявлена у $76(78,4 \%)$ пацієнтів, у тому числі у $12(41,4 \%)$ дітей з перфорацією відростка (рис. 4).

Наявність випоту має низьку чутливість $(41,4 \%)$ та високу специфічність $(94,1 \%)$ щодо наявності перфоративного апендициту, що відповідає даним літератури [7].

\section{Висновки}

Ультрасонографія має високу специфічність, проте досить низьку чутливість для визначення наявності перфоративного апендициту у дітей. 3більшення максимального діаметра червоподібного відростка, потовщання його стінки (>3 мм) та порушення ехогенності підслизового шару можна розглядати як основні УСГ-ознаки перфоративного апендициту у дітей, проте вони повинні оцінюва- 
тись лише у комплексі з даними об'єктивного обстеження та іншими УСГ-ознаками.

Автор заявляє про відсутність конфлікту інтересів.

\section{References/Лiтература}

1. Alloo J, Gerstle T, Shilyansky J et al. (2004). Appendicitis in children less than 3 years of age: a 28 -year review. Pediatr Surg Int.19(12): 777-779. doi:10.1007/s00383-002-0775-6

2. Bansal S, Banever GT, Karrer FM et al. (2012). Appendicitis in children less than 5 years old: influence of age on presentation and outcome. Am J Surg. 204(6): 1031-1035. doi:10.1016/j.amjsurg.2012.10.003

3. Blumfield E, Nayak G, Srinivasan R et al. (2013) Ultrasound for differentiation between perforated and nonperforated appendicitis in pediatric patients. AJR Am J Roentgenol. 200(5): 957-962. doi:10.2214/AJR.12.9801

4. Carpenter JL, Orth RC, Zhang W et al. (2017) Diagnostic performance of US for differentiating perforated from nonperforated pediatric appendicitis: a prospective cohort study. Radiology. 282 (3): 160-175. doi:10.1148/radiol.2016160175

5. Goldin AB, Khanna P, Thapa M et al. (2011). Revised ultrasound criteria for appendicitis in children improve diagnostic accuracy. Pediatr Radiol. 41(8): 993-999. doi:10.1007/s00247-011-2018-2

6. Gongidi P, Bellah RD. (2017). Ultrasound of the pediatric appendix. Pediatr Radiol. 47(9): 1091-1100. doi:10.1007/s00247017-3928-4

7. Gonzalez DO, Lawrence AE, Cooper JN et al. (2018). Can ultrasound reliably identify complicated appendicitis in children? J Surg Res. 229: 76-81. doi:10.1016/j.jss.2018.03.012

8. Janitz E, Naffaa L, Rubin M, Ganapathy SS. (2016). Ultrasound evaluation for appendicitis focus on the pediatric pop- ulation: a review of the literature. J Am Osteopath Coll Radiol. 5(1): 5-14.

9. Kessler N, Cyteval C, Gallix B et al. (2004). Appendicitis: evaluation of sensitivity, specificity, and predictive values of US, Doppler US, and laboratory findings. Radiology. 230(2): 472-478. doi:10.1148/radiol.2302021520

10. Koberlein GC, Trout AT, Rigsby CK et al. (2019). ACR appropriateness criteria ${ }^{\star}$ suspected appendicitis - child. J Am Coll Radiol. 16(5): S252-S263. doi:10.1016/j.jacr.2019.02.022

11. Lee MW, Kim YJ, Jeon HJ, Park SW et al. (2009). Sonography of acute right lower quadrant pain: importance of increased intraabdominal fat echo. AJR Am J Roentgenol. 192(1): 174-179. doi:10.2214/AJR.07.3330

12. Levin DE, Pegoli WJr. (2015). Abscess after appendectomy: Predisposing factors. Adv Surg. 49: 263-280. doi: 10.1016/j.yasu.2015.03.010

13. Leung B, Madhuripan N, Bittner K et al. (2019). Clinical outcomes following identification of tip appendicitis on ultrasonography and CT scan. J Pediatr Surg. 54(1): 108-111. doi:10.1016/j. jpedsurg.2018.10.019

14. Park NH, Oh HE, Park HJ, Park JY. (2011). Ultrasonography of normal and abnormal appendix in children. World J Radiol. 3(4): 85-91. doi:10.4329/wjr.v3.i4.85

15. Rawolle T, Reismann M, Minderjahn MI et al. (2019). Sonographic differentiation of complicated from uncomplicated appendicitis. Br J Radiol. 92(1099): 20190102. doi:10.1259/bjr.20190102

16. Riedesel EL, Weber BC, Shore MW et al. (2019). Diagnostic performance of standardized ultrasound protocol for detecting perforation in pediatric appendicitis. Pediatr Radiol. doi:10.1007/ s00247-019-04475-5

17. Swenson DW, Ayyala RS, Sams C, Lee EY. (2018). Practical imaging strategies for acute appendicitis in children. AJR Am J Roentgenol. 211(4): 901-909. doi:10.2214/AJR.18.19778

\section{Відомості про авторів:}

Никифорук Олеся Мирославівна - к.мед.н., асистент каф. дитячої хірургї Львівського НмУ імені Д. Галицького. Адреса: м. Львів, вул. Лисенка, 31. https://orcid.org/0000-0003-2967-5653

\section{Зміни в оформленні списку літератури}

Згідно з Наказом МОН України № 40 від 12.01.2017 р. «Про затвердження вимог до оформлення дисертацій» вносяться зміни в оформлення списку літератури у журналі. Відтепер оформлення здійснюється відповідно до стилю APA (American Psychological Association style), що використовується у дисертаційних роботах.

Журнальна публікація

\section{Приклади оформлення літературних джерел}

Автор АА, Автор ВВ, Автор СС. (2005). Назва статті. Назва журналу. 10(2); 3: 49-53.

Книга

Автор АА, Автор ВВ, Автор СС. (2006). Назва книги. Місто: Видавництво: 256.

Глава у книзі

Автор АА, Автор ВВ, Автор СС. (2006). Назва розділу (глави). У кн. Автор книги. Назва книги. Під ред. Прізвище СС. Місто: Видавництво: 256.

Інтернет-ресурс

Автор AA, Автор BB, Автор СС. (2006). Назва статті. Назва журналу/книги (якщо є). URL-адреса публікації.

Оформлення літератури за новими вимогами підвищить можливості пошукових ресурсів в Інтернеті, та, як наслідок, цитованість авторів. 